\title{
A TECHNOPEASANT RECANTS
}

\author{
M.T. Dohaney
}

I went into the dark night of the micro chip age with fear and trepidation. I trembled whenever I perceived the wide gorge that separated mere earthlings (in whose number I could be counted) from those lofty beings who inhabited the mysterious realm of high tech. I whimpered over the injustice of life that would place a technopeasant in a world enthralled with computer technology. But even as I whimpered, I knew that the inevitable was near at hand and that one day, like the death spectre, the micro chip would eventualiy claim me for its own.

To stave off this eventuality, I quickened my pace whenever, enroute to my class in written communication, I passed the computer room in the basement of the faculty of forestry. Even before I got near the room I always hugged the far wall of the corridor, much as I had hugged the far edge of the road when I was a child and had to pass a cemetery on my way to school.

To further keep the evil of technology at bay, I made ingratiating remarks about it. For example, when I was told that a state of the art wordprocessor could, in the time it took to press a button, add and delete text, write in italics, even set up tables, I asked derisively "So what's the rush?"

I also gave a wide berth to the office of any colleague whose desk sported a portable box of what I snidely cal?ed "silicon intellect." The box always languished on a desk like a spellbound prince waiting to be released from his stupor. A flick of a switch was enough to break the spell and allow this micro-chip being to begin making persistent and insistent noises. The instant it was released, it whirred and beeped and rang bells and demanded attention until the harried owner crouched in front of its blue-green face and beseeched it to tell him where it hurt or what it wanted.

I protested vehemently when my colleagues suggested I replace my antiquated, but reliable and undemanding, typewriter with a computer cum wordprocessor. The apostles of the new technology assured me I had to be certifiably insane not to make the change-over. They pointed out that even if nothing else were gained, I would save a mint on correction fluid. Because my electric typewriter predates the inciusion of a correction feature, my hands, my face and my clothes have always borne witness to the many typographical errors I have camouflaged with "white-out." My typewriter has always looked as if it had a terminal case of dandruff. 
But entreaties to change notwithstanding, I still held firm for many years against the encroachment of technology. Nevertheless, just as I feared, the inevitable came to pass. This summer--otherwise known as the summer of my conversion--I finally made the change-over. I was lured into making the change. Nay, I was inveigled into it. A colleague brought a portable computer cum wordprocessor to my office and dared me look on while he typed a page of manuscript.

The box whirred and beeped just as I had heard it do on various other occasions. It rang bells and made Circe-like come-hither noises, which I tried to ignore. Eventually my inquisitiveness became aroused to such a fevered pitch that I inched closer to the desk to get a better look at what was taking place. With a flick of his wrist and the expertise of a streetcorner pitchman, my colleague went into action. He inserted and deleted text, corrected spelling, and cut and pasted paragraphs. He even double spaced and single spaced with wild abandon, displaying rulers with a "now you see them, now you don ' $t$ " sleight of hand. When he had a change of mind about a word choice--deciding to use "would" instead of "should"--he told the box to find all the should's and make the change for him. In a final flourish, he touched a key and out of an adjoining box came a page of print as pure as the driven snow, unsullied by thumbmarks, unmarred by strike-overs and free of inounds of hardened white liquid.

It was magic! It bordered on sorcery! I was so over-awed that I recanted there and then. From that day forward I stopped bending, stapling, mutilating and maligning the computer cum wordprocessor.

almost consigned my whitener-splattered typewriter to the city dump. Almost! In a last vestige of sanity, I ordered a reprieve. For this modicum of rational thought, I have been very thankful.

Today my typewriter resides peacefully beside my wordprocessor--a case, so to speak, of the lamb lying down with the lion. I use both machines with equal frequency. In the beginning stages of composing, the wordprocessor hamstrings whatever creative stirrings I may have. For some reason, when I sit before the screen I feel compelied to type something. Anything! The flashing icon badgers me to start typing and stop ruminating on an idea. As a result, half-jelled ideas go to print.

Also at the beginning of the composing process, I need the outward signs of my fits and starts in order to keep me pushing onward. I need to see manifestation of my struggles, such as is evidenced by the $x^{\prime} s$ and dashes, the write-overs and the strike-overs. When you commit to the processor words or phrases which in hindsight are neither succinct nor definitive, a touch of a button can make them disappear. Voila! Vo more cloudy words. No more murky phrases. Voila! An empty screen! But if there is anything more forbidding and Tess motivating than an empty page, it is an empty screen.

Another drawback that I find with early-stage composing on the wordprocessor is that $I$ am not allowed the luxury of changing my inind 
and recapturing something I earlier discarded. When material is consigned to the nether worid of the processor, it is gone forever. This is not the case with the typewriter. The text lies there, in the hope of resurrection, buried deep under $x^{\prime} s$ and dashes. I cannot count the mornings I have sat with yesterday's work in hand trying to reconstruct from beneath the strike-outs memorable words or phrases I so cavalierly discarded the day before.

When the homestretch is in sight, however, and when material has been molded and melded to a reasonable degree of satisfaction, there is nothing, as far as I'm concerned, to equal the efficiency of the wordprocessor. It is like driving in the fast lane on a major highway. When you know where you are going and you want to get there in a hurry, the wordprocessor is at its most effective best.

Using this same analogy, the typewriter is a drive down a country road in an early-model car. You can poke along without someone honking at you to get moving. You can take interesting detours. You can even pull over to the shoulder of the road and get out and smell the flowers that grow in the ditch. And you may make some interesting finds by doing that.

Since my conversion I now believe that, indeed, all things are possible under heaven and earth and, therefore, it is possible that the day may come when I will only choose the fast-lane highway. (I may even learn to type envelopes and fill out forms on the wordprocessor.) As of this writing, however, I do not entertain such total conversion as a probability and I would giadly go to my grave an unrepentant and unremorseful technopeasant rather than part with my antiquated typewriter. But such sacrifice will not be necessary. I see no reason why the lion cannot continue to lie down with the lamb and thereby give to us what each has to offer.

M.T. (Jean) Dohaney teaches technical writing in the Department of Forest Resources at the University of New Brunswick. This essay builds on an earlier piece published in The Technical Writing Teacher. 